\title{
Structure-Properties Relationship of TRIP-assisted Steels by Non-destructive Testing Method
}

\author{
Animesh Talapatra ${ }^{1, *}$, Jayati Datta², N.R.Bandhyopadhyay ${ }^{3}$ \\ ${ }^{1}$ MCKV Institute of Engineering (affiliated WBUT), 243 G.T.Road, Howrah, West Bengal, PIN-711204, India \\ ${ }^{2}$ Chemistry Dept, Howrah, West Bengal, India and BESU, Shibpur, Howrah, West Bengal, India \\ ${ }^{3}$ School of Materials Science and Engineering, BESU, Shibpur, Howrah, West Bengal, India \\ *Corresponding Author: animesh talapatra@yahoo.co.in
}

Copyright (C 2013 Horizon Research Publishing All rights reserved.

\begin{abstract}
This study was conducted on two TRIP-assisted steels (having low temperature $\left(-40^{\circ} \mathrm{C}\right)$ high Charpy impact value) designated $\mathrm{A}$ (having no $\mathrm{Cr}$ and $\mathrm{Cu}$ content, $\mathrm{VHN}=169, \mathrm{UTS}=542 \mathrm{MPa}$ ) and $\mathrm{B}$ (having higher $\mathrm{Ni}$, $\mathrm{Cr}$ and $\mathrm{Cu}$ content, $\mathrm{VHN}=217$, UTS $=657 \mathrm{MPa}$ ). These steels were heattreated under different conditions to investigate correlation between heat treatment, microstructure and different properties. Micro-structural characterizations were carried out by optical microscope and scanning electron microscope after electrolytic etching. Non-destructive electro-chemical and ultrasonic testing on two TRIP-assisted steels were used to find out corrosion and mechanical properties of different alter microstructure phase's steels. Furthermore, micro-structural studies accompanied by the evaluation of mechanical properties revealed that steels having martensite phases with higher corrosive and hardness value were less sound velocity and also steel's microstructure having finer grains that was more grain boundary was less corrosion resistance. Steel containing more $\mathrm{Cu}, \mathrm{Ni}$ and $\mathrm{Cr}$ was less corrosive compared to other steels having same processing or microstructure i.e. $R p(B)>R p(A)$. The additions of alloying elements, such as $\mathrm{Cu}, \mathrm{Cr}, \mathrm{Mo}, \mathrm{Ni}$, etc. within the rust layer contribute to the improvement of electro-chemical characteristic of TRIP assisted steel. The corrosion current or $\mathrm{i}_{\text {corr }}$ increases and corrosion resistance or $\mathrm{R}_{\mathrm{p}}$ decreases with increasing $\mathrm{Cl}^{-}$ions in solution up to a threshold value beyond which the corrosion rate starts to decrease.
\end{abstract}

Keywords TRIP-assisted steels, heat treatment, corrosion, electro-chemical techniques, micro-structural characterization, non-destructive (ultrasonic) technique

\section{Introduction}

\subsection{Literature Review on TRIP Assisted Steels}

The automotive industries pay a great deal of attention to development of the new classes of steels with enhanced combination of strength-formability for more affordable, safe and fuel-efficient vehicles. From the 1950's to the 1960 's, the rimmed steel was researched and used. From the 1960 's to 1970 's, many killed steels were developed and employed. From the 1980's to the 1990's, to highly improve the formability of sheet steel, the research of auto steel was mainly centralized in interstitial-free (IF) steel. By the $21^{\text {st }}$ century, most projects of auto steel focused on developing new kinds of HSS and new style steels to meet the needs of the plan of ultra light steel auto body (ULSAB).These steels include double-phase (DP) steel, TRIP-steel and TWIP-steel. Transformation induced plasticity (TRIP) aided steels and twinning induced plasticity (TWIP) aided steels are the promising candidates fulfilling such demands Ref [1]-[3].The main difference between TRIP-assisted and TWIP steel is that the austenite in the former is stable on cooling but not under mechanical load, i.e. phase transformation happens when the material is loaded. In contrast, there is no phase transformation in TWIP steel during cooling or deformation, but the orientation of part of austenite will change due to mechanical twinning. The different behavior of the austenite is attributed to its stacking fault energy (SFE). If SFE is very low $\left(<20 \mathrm{~mJ} / \mathrm{m}^{2}\right)$, martensitic-induced plasticity is favoured Ref [4]. Higher SFE of the order $25 \mathrm{~mJ} / \mathrm{m}^{2}$ suppresses martensitic phase transformation and favours mechanical twinning until SFE values $<60 \mathrm{~mJ} / \mathrm{m}^{2} \operatorname{Ref}[5]$ ]-[6]. Steels having a fully austenitic microstructure are called TRIP steels Ref [3]. These steels tend to be rich in nickel and other expensive austenite stabilizing elements. By contrast, austenite is only a minor phase in the overall microstructures of TRIP-assisted steels Ref [7].

Some authors investigated the general corrosion resistance of $\mathrm{Cr}-\mathrm{Ni}-\mathrm{C}$ and $\mathrm{Cr}-\mathrm{Ni}-\mathrm{Mo}-\mathrm{C}$ TRIP steels, utilizing an anodic polarization testing procedure Ref [8]-[9]. They found that $13 \mathrm{Cr}-8 \mathrm{Ni}-3 \mathrm{Mo}-0.25 \mathrm{C}$ and $13 \mathrm{Cr}-7 \mathrm{Ni}-4 \mathrm{Mo}-0.25 \mathrm{C}$ TRIP steels have both very good mechanical and very good corrosion-resistant properties. There was no information, 
however, on the resistance of TRIP steels to localized attack (pitting corrosion), especially in chloride solutions, including sea-water. Nor was there in form formation on the corrosion resistance of TRIP steels that have been cold-worked and thus partly transformed to Martensite. Corrosion of automotive components by road salt is a widely known problem. The different parts under the car body and the interior surface of body panels suffer easily from the corrosive products deposited on roads and used mainly to melt snow. Automotive corrosion is classified into three types' perforation corrosion, cosmetic corrosion and edge corrosion. In moderate-velocity and high velocity sea atmosphere, $\mathrm{Ni}$ base alloys have excellent resistance to cavitations, erosion and exhibits corrosion rates of less than $0.025 \mathrm{~mm} /$ year. Other Ni-base alloys containing $\mathrm{Cr}$ and Mo offer increased resistance to localized corrosion in stagnant sea atmosphere. There are so many factors and elements responsible for corrosion but the most important ones to consider are; oxygen, formation fluids, drilling mud, water and carbon dioxide, high velocity sand, hydrogen sulphide and complications from temperature, pressure and stress Ref [11]-[13].

\subsection{Purpose of the Study}

Keeping in view above study on corrosion behaviours to moderately low carbon steels having $\mathrm{Si}, \mathrm{Mn}, \mathrm{Ni}, \mathrm{V}, \mathrm{Nb}, \mathrm{Mo}$ and/or $\mathrm{Cu}$ and $\mathrm{Cr}$, designed and develop for naval application has been attempted in this study. Electro-chemical test under simulated condition of marine atmosphere both at laboratory stage and real seawater condition, beside immersion test by varying the control parameters viz. exposure time, influence of $\mathrm{pH}$, salinity etc. are the methodology that would be adopted for evaluation of corrosion-characteristics.

No data base being available in literature on the systematic study on effect of corrosion on multi-phases microstructure. Efforts are being made to find out a correlation between heat treatment, post and pre-corrosion microstructure with corrosion behaviour of the steels. The microstructure after heat-treatment consists of ferrite, bainite, retained austenite and sometimes, martensite. The excellent mechanical properties exhibited by Transformation Induced Plasticity steels are mainly due to the martensite transformation of the metastable retained austenite induced by strain. The stability Ref [10]-[12] of retained austenite depends on the carbon content in the retained austenite lattice (chemical stability), the size and the distribution of residual austenite as well as the morphology of the surrounding phase (mechanical stability). It has also been observed that the optimum elongation behaviour is obtained when the retained austenite is present in the microstructure in the form of the thin films between the bainitic ferrite laths rather than as a blocky type between the bainitic ferrite grains. TRIP-aided steel are composed of four phases forming a very fine microstructure which makes their observation difficult. For light microscopy observation, some specific etchants have been tested.

It is essential to do more study in corrosion behaviour and performance of the material in order to evaluate and improve the design, cost effectiveness and reliability of each material used. Khoshnaw Ref [10] studied fatigue strength of low alloy steels in chloride solution. Turnbull Ref [12] studied stress corrosion cracking of stainless steel in chloride solutions. Chen Ref [11] studied mechanical properties of low-alloy steels in atmosphere containing chloride in tension test.

\section{Experimental Procedures}

\subsection{Materials}

Two moderately low Carbon high strength low alloy steels for sea atmosphere automotive application are designated as $\mathrm{A}$ and $\mathrm{B}$ having composition given in Table 1.They were supplied by DMRL, Hyderabad, India.

\subsection{Heat Treatment}

Steels were heat treated as per schedules as shown in below in Table 2 to develop different microstructure phases in different steels.

\subsection{Optical Micrograph}

The micro structural characterizations of the steels were carried out using an OLYMPUS CK4OM-CP optical microscope. The optical metallographies of all these samples were carried out in the usual way. Samples were cut from plates of theses steels. These samples were polished on polishing wheel after 1 to 6 (rough to fine) emery papers. The polished surface appeared like mirror having no scratches and the etchant was used 2\% nital. The washed and dried samples were observed carefully in Microscope at different magnification and some selected photomicrographs were taken. TRIP-aided steel are composed of four phases forming a very fine microstructure which makes their observation difficult. For light microscopy observation, some specific etchants have been tested. 
Table 1. Chemical composition of Steel A \& Steel B

\begin{tabular}{|l|l|l|l|l|l|l|l|l|l|l|}
\hline Steel & C & Mn & Si & P & Ni & Cr & Cu & V & Nb & Mo \\
\hline A & 0.1 & 1.3 & 0.3 & 0.02 & 0.7 & 0 & 0 & 0.03 & 0.03 & 0 \\
\hline B & 0.1 & 0.4 & 0.2 & 0.02 & 2 & 0.4 & 0.6 & 0.03 & 0 & 0.4 \\
\hline
\end{tabular}

Table 2. Heat treatment of steels

\begin{tabular}{|c|c|c|c|}
\hline Steel & $\begin{array}{c}\text { Serial } \\
\text { no }\end{array}$ & Heat treatment & Designation \\
\hline \multirow{6}{*}{ A } & 1 & $\begin{array}{l}\text { As received (oil quenched and } \\
\text { tempered) }\end{array}$ & $\mathrm{A}_{1}$ \\
\hline & 2 & $\begin{array}{l}\text { Held at } 950^{0} \mathrm{C} \text { for } 1 / 2 \mathrm{hr} \text {, air } \\
\text { cooled, Held at } 700^{0} \mathrm{C} \text { for } 2 \mathrm{hrs} \text {, } \\
\text { quenched to } 400^{0} \mathrm{C} \text { (salt bath), } \\
\text { held for } 900 \mathrm{~s} \text { and oil quenched. }\end{array}$ & $\mathrm{A}_{2}$ \\
\hline & 3 & $\begin{array}{c}\text { Held at } 950^{\circ} \mathrm{C} \text { for half an hour, } \\
\text { oil quenched in an oil of } \\
0.123 \text { centistokes viscosity. }\end{array}$ & $\mathrm{A}_{3}$ \\
\hline & 4 & $\begin{array}{l}\text { Held at } 950^{\circ} \mathrm{C} \text { for half an hour } \\
\text { then cooled in water }\end{array}$ & $\mathrm{A}_{4}$ \\
\hline & 5 & $\begin{array}{l}\text { Held at } 950^{0} \mathrm{C} \text { for } 1 / 2 \mathrm{hr} \\
\text { then cooled in air }\end{array}$ & A5 \\
\hline & 6 & $\begin{array}{l}\text { Held at } 950^{0} \mathrm{C} \text { for } 1 / 2 \mathrm{hr} . \text {, and } \\
\text { then cooled in furnace by } \\
\text { switching off. }\end{array}$ & $\mathrm{A}_{6}$ \\
\hline \multirow{6}{*}{ B } & 1 & $\begin{array}{c}\text { As received (water quenched and } \\
\text { tempered) }\end{array}$ & $\mathrm{B}_{1}$ \\
\hline & 2 & $\begin{array}{l}\text { Held at } 970^{0} \mathrm{C} \text { for } 1 / 2 \mathrm{hr} \text {, air coo } \\
\text { led, Held at } 800^{0} \mathrm{C} \text { for } 2 \mathrm{hrs,} \\
\text { quenched to } 400^{0} \mathrm{C} \text { (salt bath), } \\
\text { held for } 900 \mathrm{~s} \text { and oil quenched. }\end{array}$ & $\mathrm{B}_{2}$ \\
\hline & 3 & $\begin{array}{l}\text { Held at } 970^{\circ} \mathrm{C} \text { for half an hour, } \\
\text { oil quenched in } 0.123 \text { centistokes } \\
\text { viscosity }\end{array}$ & B3 \\
\hline & 4 & $\begin{array}{l}\text { Held at } 970^{\circ} \mathrm{C} \text { for half an hour, } \\
\text { cooled in water }\end{array}$ & B4 \\
\hline & 5 & $\begin{array}{l}\text { Held at } 970^{\circ} \mathrm{C} \text { for half an hour, } \\
\text { then cooled in air }\end{array}$ & B5 \\
\hline & 6 & $\begin{array}{l}\text { Held at } 970^{\circ} \mathrm{C} \text { for } 1 / 2 \mathrm{hr} . \text {, then } \\
\text { cooled in furnace by switching } \\
\text { off. }\end{array}$ & $\mathrm{B}_{6}$ \\
\hline
\end{tabular}

\subsection{Phase Analysis}

This is used to estimate the area percentage of different phase's composition of material. In phase analysis thresholding images can be done by different color. It is calculated area $\%$ and area of selected Phase in different colors. Single Phase can be done by simply clicking on particular portion and it can be reset or deleted. It allows user to acquire, process, and analyze the images of the polished sections when it is necessary to estimate the area percentage of different phases. If the image is color or $b / w$ (depending on the image) the program starts its processing. The phases for (e.g. different minerals, inclusions in the metals, etc.) are threshold. For phase thresholding the $\mathrm{B} / \mathrm{W}$ or Color manual thresholding method is used. If you are not satisfied with their thresholding there is an ability to adjust it by moving the graphical sliders. The phase analyses ASTM
E 5661245 have been done by using Olysia m3 software. Samples were prepared as like as preparation of sample for optical microscope observation. Then images were taken in optical microscope. The acquired images of a multiphase object were taken for analysis. Phase analysis will be conducted on a gray-value image. The image is selected and threshold is set to define the gray value ranges for the separate phases. The OLYSIA software created a measurement sheet showing the absolute area and proportional area (in \%) of all the phases. The measured values are taken.

\subsection{Electro-chemical study}

\subsubsection{Samples and Solution preparation}

Cutting samples were polished on belt followed by polishing on polishing wheel (rough to fine) emery papers. The polished surface appeared like mirror having no scratches. They were then degreased with acetone before exposing to the electro-chemical test. Solution of $0 \%, 0.1 \%$, $1 \%$ and $3 \% \mathrm{NaCl}$ at $\mathrm{pH} 7$ (Nearly) were prepared with triple distilled water.

\subsubsection{Polarization Study}

Samples were taken in an area of 0.204 square $\mathrm{cm}$ size coupons for performing potentiodynamic polarization studies in de-aerated condition in cells with three electrodes (working electrode, aqueous saturated calomel SCE (W) as the reference electrode and $\mathrm{Pt}$ foil as counter electrode). Linear sweep voltammetry was preformed with the help of AUTOLAB 12 PGSTAT, Eco Chemic B.V (the Netherlands) at $0.5 \mathrm{mV} / \mathrm{s}$ scan rate within the potential range of $-1500 \mathrm{mV}$ to the cathodic potential of $650 \mathrm{mV}$ vs.SCE. Potential scans were conducted in de-aerated conditions by purging the solution with nitrogen for $10 \mathrm{~min}$.Tafel analysis was perfomed to determine the corrosion parameters. The relationship between current density and potential of anodic and cathodic electrode reactions under charge transfer control is given by the Butler-Volmer equation.

\subsubsection{Electro-chemical Impedance Spectroscopy}

EIS at the respective OCP value were recorded with the help of AUTO-LAB 12 PG STAT, Eco Chemie B.V (the Netherlands) combined with frequency response analyser (FRA) module. The sinusoidal perturbation of $5 \mathrm{mV}$ amplitude was applied at the cell over the frequency range of $100 \mathrm{kHz}$ to $10 \mathrm{mHz}$. EIS measurements were conducted at open circuit conditions after a steady state potential was attained in aerated solution of different electrolytes at neutral 
$\mathrm{pH}$. The experiment was performed in three electrode one compartment cell containing the test coupons as working electrode, a large area Pt foil as counter electrode and a saturated calomel reference.

\subsection{Nondestructive Testing}

The measurements of the ultrasonic velocities were accomplished using a longitudinal and transverse wave transducer. The technique used was the pulse echo based on the direct contact with the sample. To measure the velocities of longitudinal waves, it was used a normal incidence transducer of 5 and $10 \mathrm{MHz}$.The EPOCH4 ultrasonic flaw detector with its high voltage pulse, the quality of its square pulse and selectable narrowband filters is the instrument of choice for this technique.With the values of material densities and ultrasonic velocities (longitudinal and transverse waves), the elastic modulus was calculated based on the ASTM E 494-1995 norm (Measuring Ultrasonic Velocity in Materials) using the equation. After the measurements of the longitudinal and transversal wave ultrasonic velocities, the elastic modulus of each samples were calculated, considering the ASTM E 494-95 norm. According to the ASTM E-494-05 norm, the results for the elastic modulus obtained by ultrasound testing have an error around $1 \%$ in comparison to the values obtained by mechanical testing. Elastic modulus is related to the inter-atomic forces and hence indicates maximum attainable strength. There exists a direct mathematical relationship between elastic modulus and ultrasonic longitudinal and shear velocity.

$$
\begin{array}{ll}
\mathrm{L}=\rho \mathrm{U}_{1}^{2} & \mathrm{G}=\rho \mathrm{U}_{\mathrm{s}}^{2} \\
\sigma=\left(\frac{\mathrm{L}-2 \mathrm{G}}{2(\mathrm{~L}-\mathrm{G})}\right) & \mathrm{H}=(1-2 \sigma) \frac{\mathrm{E}}{6(1+\sigma)} \\
\mathrm{E}=(1+\sigma) 2 \mathrm{G} &
\end{array}
$$

These relationships are as follows:

i) Young's Modulus $\mathrm{E}=\rho \cdot \mathrm{V}_{\mathrm{T}}^{2} \cdot\left(3 \mathrm{~V}_{\mathrm{L}}^{2}-4 \mathrm{~V}_{\mathrm{T}}^{2}\right) /\left(\mathrm{V}_{\mathrm{L}}^{2}-\mathrm{V}_{\mathrm{T}}^{2}\right)$, ii ) Shear Modulus $G=\rho \cdot V_{T}^{2}$,

iii ) Bulk Modulus $\mathrm{B}=\rho \cdot\left(\mathrm{V}_{\mathrm{L}}{ }^{2}-4 \cdot\left(\mathrm{V}_{\mathrm{T}}{ }^{2}\right) / 3\right)$,

iv ) Poisson's Ratio $v=\left(\mathrm{V}_{\mathrm{L}}^{2}-2 \cdot \mathrm{V}_{\mathrm{T}}^{2}\right) /\left(2 \cdot \mathrm{V}_{\mathrm{L}}^{2}-2 . \mathrm{V}_{\mathrm{T}}^{2}\right)$,

v ) Fracture toughness $K C$ is given by: $K_{C}=\sqrt{E}$.Gc.

$\mathrm{E}$ is the Young's Modulus; $\mathrm{Gc}$ is the strain energy release factor. Kim and Johnson et.al (2007) using resonant ultrasonic spectroscopy measured the elastic modulus of ferrite, ferrite pearlite, and martensite microstructures, being the obtained elastic modulus of $211.9,210.3$ and $203.5 \mathrm{GPa}$ and the density values of $7.851,7.835$ and $7.709 \mathrm{~g} / \mathrm{cm}^{3}$, respectively. According to Hakan and Orkun (2005), in the case of the specimens consisting of pearlite-ferrite, the main difference in the microstructure is the spacing of the cementite lamellae-ferrite, and content and size of ferritic phase. Yield strength is defined as a lower yield point or as the strength at $0.2 \%$ offset strain in case of the absence of a yield point. The work-hardening behaviour is described using the change in the instantaneous work-hardening exponent $\mathrm{n}$ is defined as the following equation evaluated from the true stress-strain curve.

\section{Results and Discussion}

\subsection{Microstructural Characteristic}

The microstructure characterization was carried out using optical microscope OLYMPUS CK4OM-CP JAPAN. Microstructures of the corroded samples were studied by optical microscope after electrolytic. The morphology of retained austenite has been classified into five different phase categories:

- Blocky shape enclosed by polygonal ferrite,

- Blocky or layer shape enclosed by acicular ferrite,

- Blocky or layer shape enclosed by bainite packets,

- Interlayer film enclosed by martensite laths,

- Austenite/ martensite constituent.

Pre corrosion samples

The optical microstructure of as received condition (A1) reveals mostly polygonal ferrite with certain amount of tempered bainite as shown in Figure1. The optical microstructure of as received condition (B1) reveals mostly tempered bainitic structure with certain amount of blocky polygonal ferrite as shown in Figure 2.

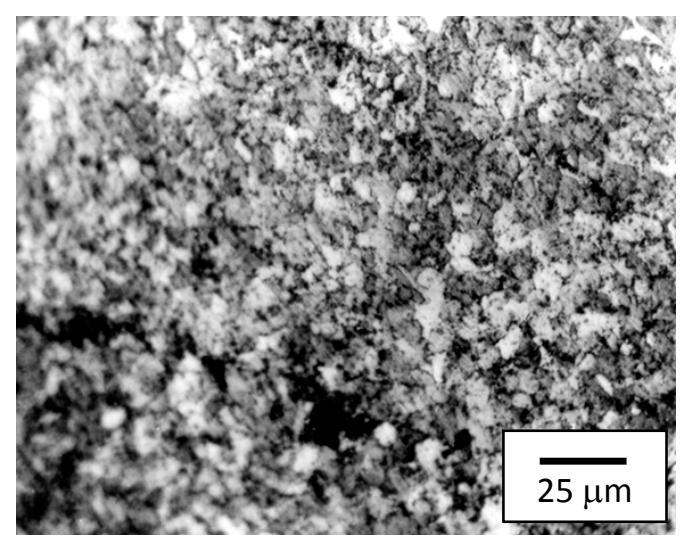

Figure 1. Microstructure of received steel $A_{1}$

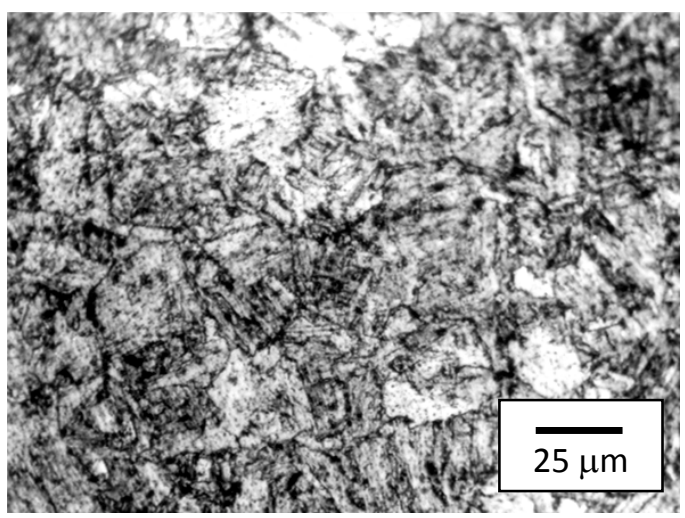

Figure 2. Microstructure of received steel $\mathrm{B}_{1}$ 
The SEM images of as received condition show mostly polygonal ferrite (A1) but microstructure with higher magnification reveals a grain boundary thickening may be due some carbide precipitation and tempered bainite (A1) as shown in Figure 3. SEM image of the steel in as received condition show mostly, acicular ferrite with some polygonal and quasi-polygonal ferrite and tempered bainite (B1) as shown in Figure 4. Etching using $0.1 \% \mathrm{NaCl}, 1 \% \mathrm{NaCl}$ solution. When the A steel was intercritically annealed and quenched in salt bath for incomplete bainitic transformation, following the conventional heat-treatment schedule of TRIP aided dual phase steel $\left(\mathrm{A}_{2}\right)$ as shown, the microstructure is, as expected, consist of granular ferrite and bainite.

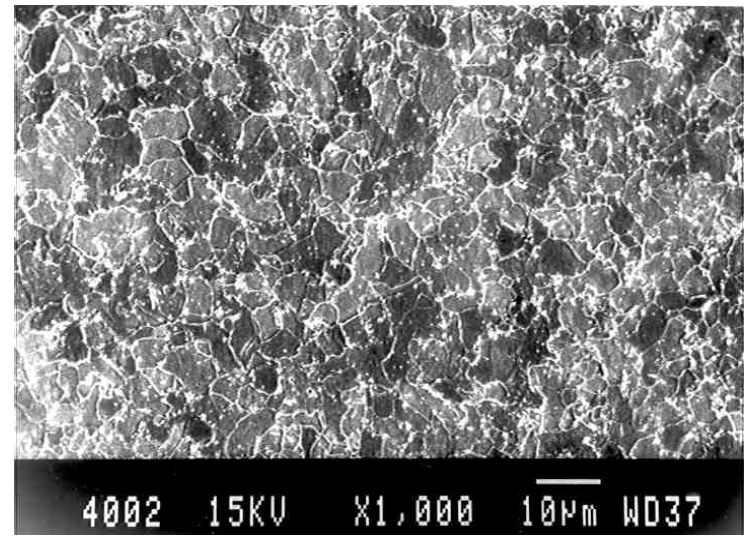

Figure 3. SEM of received steel $A_{1}$

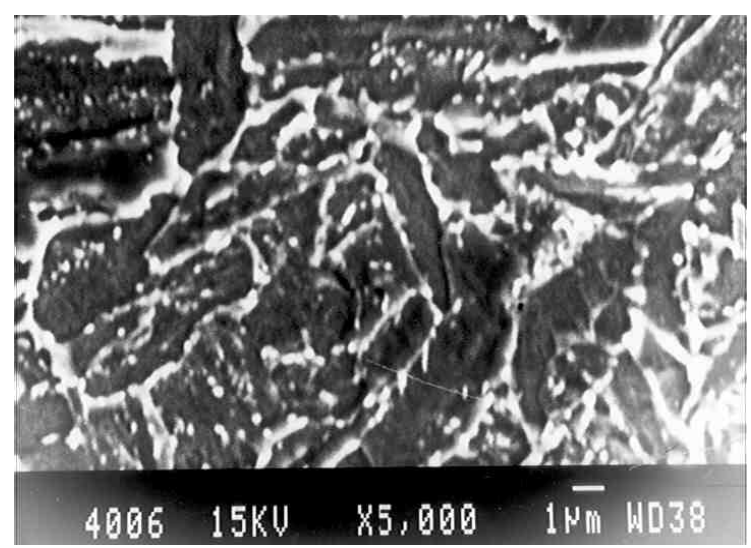

Figure 4. SEM of received steel $\mathrm{B}_{1}$

There must have been some amount of martensite-austenite (MA) constituent. The microstructures comprise of mostly acicular ferrite/ bainite with certain amount of quasi-polygonal and granular ferrite. When the steel B was heat-treated, the microstructure is found to be consisting of acicular ferrite/ bainite with some islands of polygonal and quasi-polygonal ferrite $\left(\mathrm{B}_{2}\right)$. $\mathrm{A} 2$ and $\mathrm{B} 2$ reveal granular ferrite plus bainite and granular ferrite plus tempered bainite. The microstructure of the steel continuously cooled with increasing cooling rate $\left(\mathrm{A}_{3}\right)$ i.e. decrease in viscosity of the quenching medium, has increased the acicularity of the microstructure. The microstructure of the steel continuously cooled with increasing cooling rate $\left(\mathrm{B}_{3}\right)$ as comprise of low temperature transformation product of austenite, mostly acicular ferrite/bainite with some amount of granular ferrite. Increase in cooling rate has increased the acicularity of the microstructure with some amount of martensite laths could be noticed at the structure with parallel lath groups replacing the non-parallel laths of acicular ferrites. A3 and B3 reveal acicular ferrite plus bainite and accicular ferrite. B4 as ferrite and martensite. Finally B5 reveals ferrite and pearlite.

Post-corrosion samples

Post corrosion microstructures were taken for a few samples for both steels, reveal adequate corrosion both in the form of grain boundary attack and pitting. However steel having high percentage of $\mathrm{Cu}$ and $\mathrm{Cr}$, in case of steel $\mathrm{B}$, this corrosion attack is comparatively less in all heat treatment schedules seemingly due to formation of protective oxide layer. All the above microstructure when subjected to image analysing system, it is seen that high \% of martensite and/ or pearlite in ferrite matrix during water and air cooling. Corresponding threshold images of A steel and $B$ steel as shown in Figure no-5(A), (B), (C) and 6 (A), (B), (C).
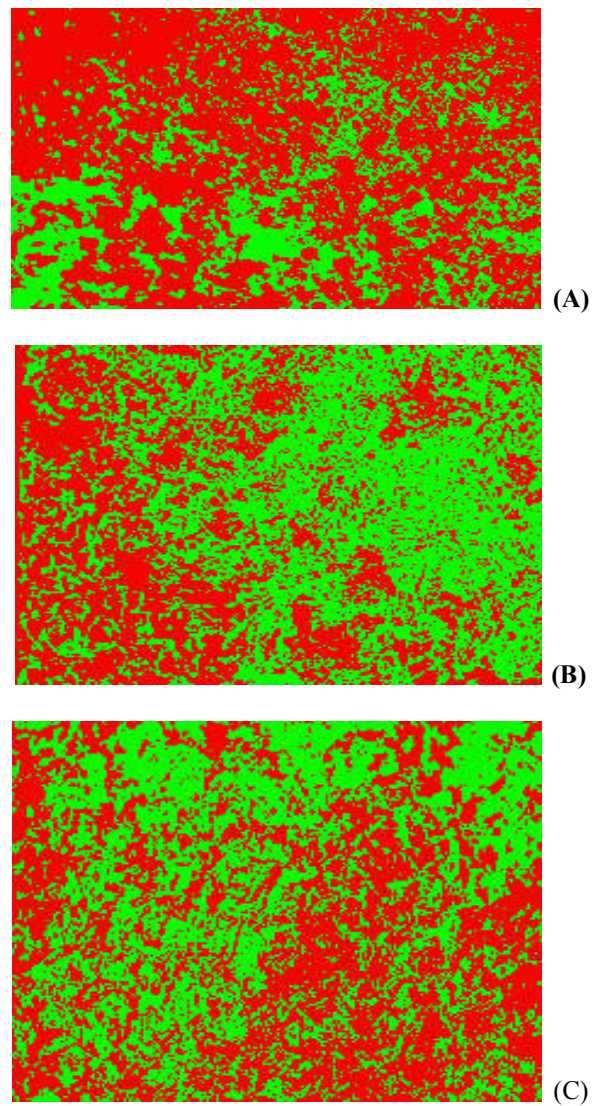

Figure 5. Corresponding threshold image of Steels (A 1), (A 2) \& (A3)

Here also B6 shows the most corrosion resistance property compared to other sample.

Alloy A when water quenched from the austenitic region A4 was found that microstructure contains around $73 \%$ martensite. When the same alloy was normalized (A5), the amount of the second phases was found to be higher but the 
corrosion behaviour of the normalized sample was found to be greater than the alloy in quenched condition (water). This may be due to fact that the amount of non equilibrium phases in A4 is much higher than A5. As the second phase in A5 may contain with some amount of bainite and mostly pearlite. When the alloy was annealed the amount of ferrite increases considerably and the second phase being pearlite. When the alloy was heat-treated accordingly schedule 2 and 3 the microstructure predominantly consists of ferrite and bainite with certain possibility of presence of martensite-austenite (MA) constituent. Though the phase analysis shows a comparable phase distribution A2 and A3, general acicularity of A3 microstructure is definitely higher and hence corrosion rate for $\mathrm{A} 3$ was also higher though marginally. A1 sample is quenched and tempered directly from the hot rolled condition.
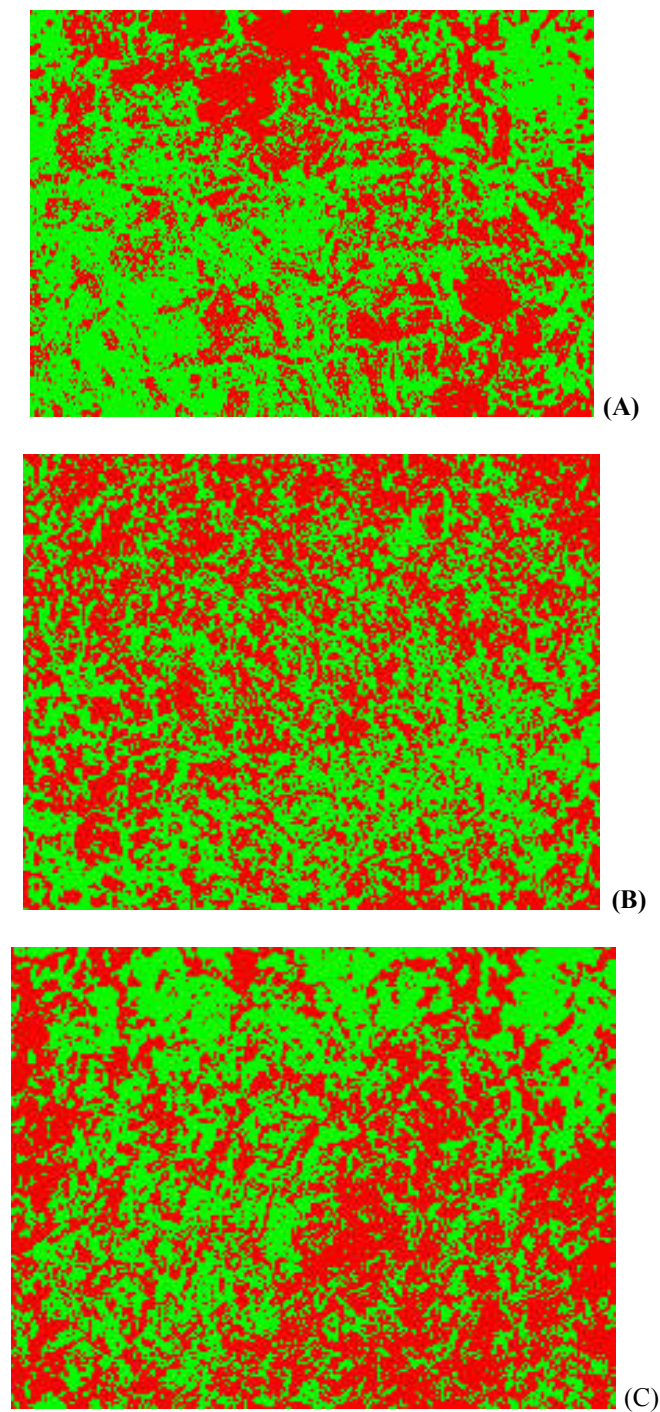

Figure 6. Corresponding threshold image of Steels (B 1), (B 2) \& ( B3 )

Though the amount of second phase's presence in microstructure is lower than $\mathrm{A} 2$ and $\mathrm{A} 3$, corrosion result shows that it has least corrosion resistance in this particular condition. This may be due to presence of high density of dislocation in microstructure, which is not possible to reveal in the microscopy made in this work. Incase of alloy B similar phenomenon could be observed in almost all the heat treated condition. Here also B6 shows the most corrosion resistance property compared to other sample. In case of B2 and B3, like alloy A, corrosion results are comparable, B3 showing A marginally lesser corrosion resistance particularly at lower concentration of $\mathrm{NaCl}$. Here also it is found that B1 is the most corrosive in nature and this may also be attributed has to presence of dislocation in the microstructure.

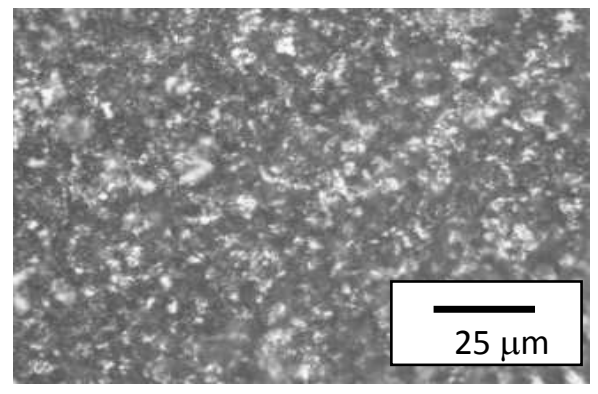

Figure 7. Microstructure Al steel in $0.1 \% \mathrm{NaCl}$

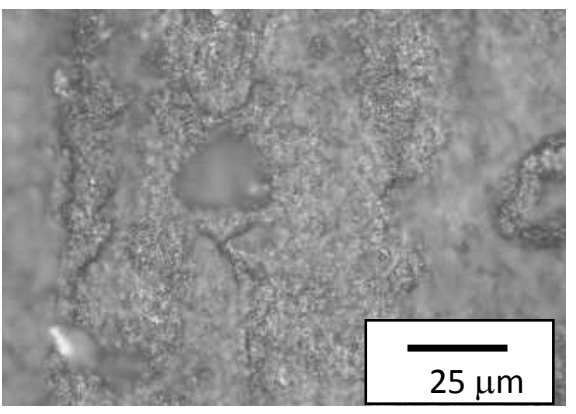

Figure 8. Microstructure $\mathrm{B} 1$ steel in $0.1 \% \mathrm{NaCl}$

Table 3. Volume fraction of micro structural phases of steel A and B

\begin{tabular}{|c|c|c|c|c|c|}
\hline Sample & Ferrite & $\begin{array}{c}\text { Tempere } \\
\mathrm{d} \\
\text { Bainite }\end{array}$ & Bainite & Pearlite & Martensite \\
\hline A1 & 70.617 & 29.382 & & & \\
\hline A2 & 46.515 & & 53.484 & & \\
\hline A3 & 52.485 & & 47.514 & & \\
\hline A4 & 26.964 & & & & 73.035 \\
\hline A5 & 13.975 & & & 86.024 & \\
\hline A6 & 52.255 & & & 47.744 & \\
\hline B1 & 43.117 & 56.882 & & & \\
\hline B2 & 50.675 & & 49.324 & & \\
\hline B3 & 56.561 & & 43.438 & & \\
\hline B4 & 23.855 & & & & 76.144 \\
\hline B5 & 29.177 & & & 70.822 & \\
\hline B6 & 75.220 & & & 24.779 & \\
\hline
\end{tabular}

It is generally found that alloy B has superior corrosion resistance property than alloy A when compared at any 
particular heat treatment condition. This is probably due to presence of $\mathrm{Cr}$ and $\mathrm{Cu}$ in alloy $\mathrm{B}$. The steel shows the highest corrosion resistance property. This is due to the presence of equilibrium phases in the microstructure.

All the above microstructure when subjected to image analyzing system and volume fraction of phase present in structure are determined (table 3). While the in the conventionally heat treated A4, A5, A6 and B4, B5, B6 volume fraction of phases of the microstructure maintained its typical behaviour of high $\%$ of martensite and/or pearlite in ferrite matrix during water and air cooling, incase of furnace cooling / annealing volume fraction of ferrite is found to be higher due to obvious reason. In case of other microstructures of both steels heat treated at different schedules having multi-phases, primarily reveal the higher percentage of nonequilibrium phases according to rate of cooling. Two major phases, in such cases, are broadly considered for further co-relation with corrosion behaviour.

\subsection{Corrosion Characteristic}

Typical polarisation plots as shown in Fig no-9 of A2 and $\mathrm{B} 2$ in $0.1 \% \mathrm{NaCl}$ shows that $\mathrm{B} 2$ is characterized with a narrow but distinct passive region while in $\mathrm{A} 2$ there is no such region. It may be predicted that matrix / grain boundary of $\mathrm{A}$ is more reactive than that of $\mathrm{B}$ in neutral conditions and that may be due to formation of thicker and stern passive layer (oxide film) in alloy B. This gets disrupted immediately in contact with $\mathrm{Cl}^{-}$. In most of $\mathrm{A}$ and $\mathrm{B}$ samples 10 -fold decrease is observed when exposed to $0.1 \% \mathrm{NaCl}$ as shown in Fig 10 (A) \& (B). However this decrease is much restricted in case of $\mathrm{B} 2$ and $\mathrm{B} 3$ samples. With further increase in $\mathrm{Cl}^{-}$ion $\mathrm{Rp}$ decrease as usual. A more or less similar behaviour is reflected with polarization studies.

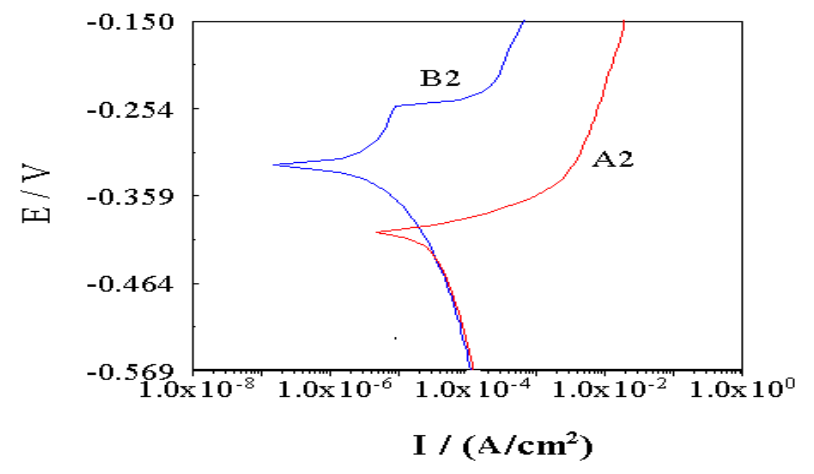

Figure 9. Polarization plot for Steel $\mathrm{A} 2$ and $\mathrm{B} 2$ in $0.1 \% \mathrm{NaCl}$ solution

EIS measurement reveals the Nyquist plot as shown in Figure no-11(A) \& (B) where the diameter of semicircles represents the circuit resistance of the material. While in pure water $(0 \% \mathrm{NaCl})$ Nyquist plots as shown in are characterized with two subsequent but overlapping semicircles, in $\mathrm{Cl}^{-}$ions containing solution only single semicircles are obtained.

In neutral $\mathrm{pH}$ when EIS represents dual character $\mathrm{B}$ samples are more resistant than A samples $R p(B)>R p(A)$.
Such conclusion can be found from tables of corrosion rate. Corrosion current or corrosion rate are much higher for $\mathrm{A}$ samples then $\mathrm{B}$ ones. Increase in $\mathrm{Cl}$ - ion concentration increases the corrosion rate in both samples as shown in Table 4 and 5 .Interestingly enough, in case of B2 and B3 samples corrosion rates are not that significantly accelerated with [Cl-] as in case of A samples. In the contrary, B2, B3 sample exhibits resistant behaviour when polarized in $0.1 \%$, even more than when studied in $0 \% \mathrm{NaCl}$.This in fact translates to a dual influence of oxidation kinetics and film repair process in the mild $\mathrm{Cl}$ - concentrations.
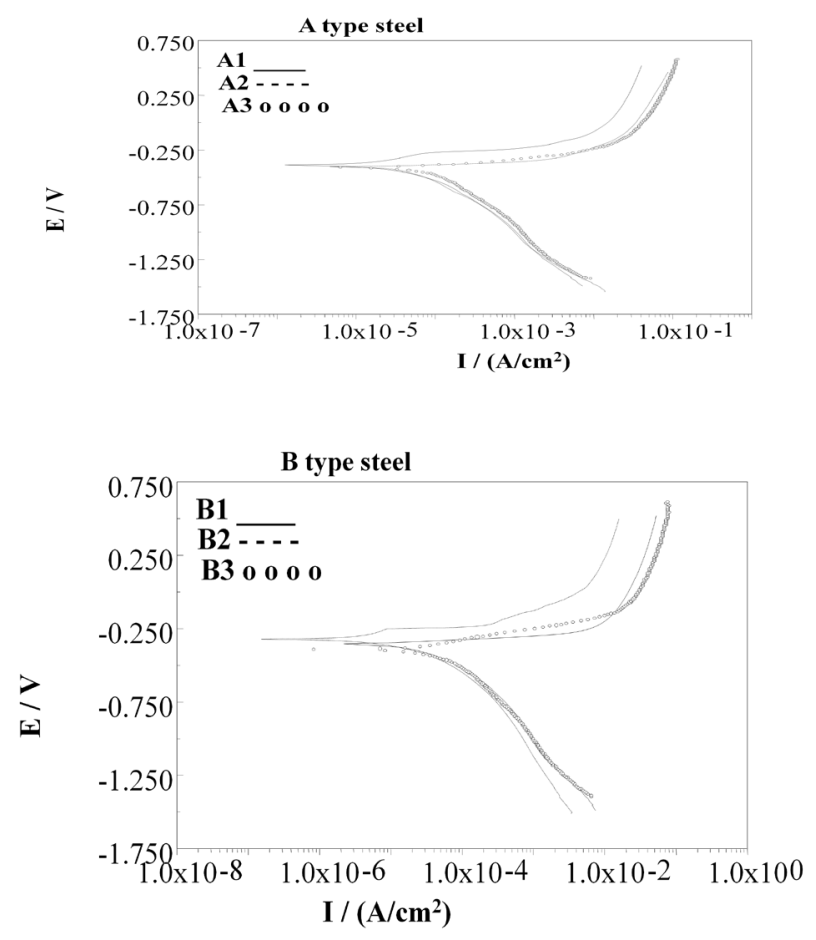

Figure 10. Polarization plot for Steel Aand $\mathrm{B}$ in $0.1 \% \mathrm{NaCl}$ solution
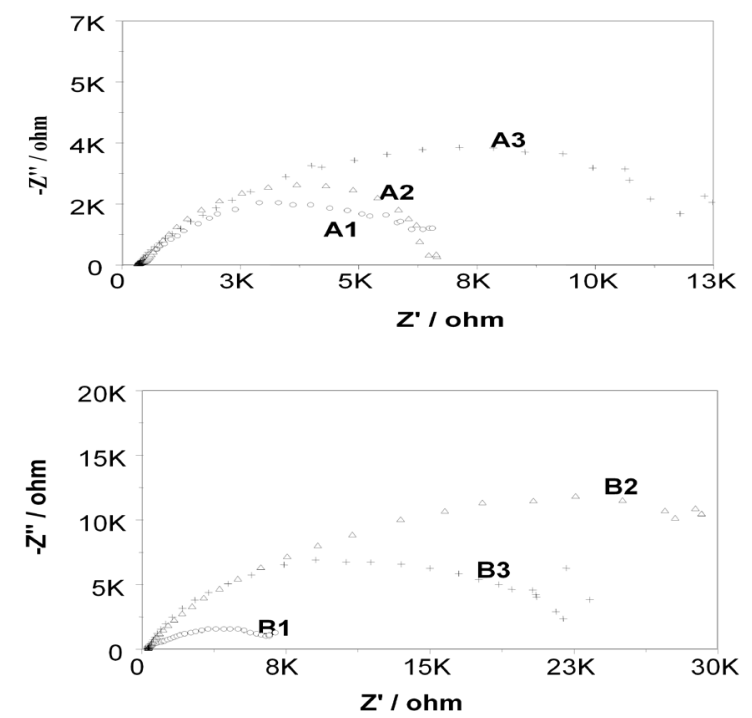

Figure 11. Nyquist plot for A steel and B steel in $0.1 \% \mathrm{NaCl}$ solution 


\subsection{Non-Destructive Characterization}

The variation of the longitudinal ultrasonic velocities in frequencies of 5 and $10 \mathrm{MHz}$, and transversal ultrasonic velocity in frequency of $5 \mathrm{MHz}$ for the samples. According to the obtained results for the longitudinal and transversal ultrasonic velocities' values, for $5 \mathrm{MHz}$, it can be noted a higher velocity for the ferrite $(5930 \pm 3$ and $3230 \pm 1)$ and lower for the martensite (5884 \pm 1 and $3180 \pm 1.2)$, being the pearlite $(5917 \pm 2.5$ and $3234 \pm 2)$ with an intermediate value as shown Figure no-12 (A) and (B). The lowest ultrasonic velocity verified for martensite can be explained by the great quantity of internal tension it presents, resulting from crystal lattice distortions caused by the increase in volume during the austenite-martensite transformation. Previous studies showed that ultrasonic velocity decreases as the plastic deformation level of the material increases, due to an increase in discrepancy density Ref [18]. According to Gür and Tuncer Ref [19], the ultrasonic velocity in martensite is essentially affected by changes in the modulus of elastic of individual grains, in the crystal lattice distortion level and in the orientation of primary austenite grains. For the materials studied and the frequencies adopted, the ultrasonic measurements show that fine grain sizes led to lower ultrasonic velocity than coarse grain sizes, this was also observed by Albuquerque et al. Ref [20]. However, the opposite behavior was reported by Palanichamy et al. Ref [21]. Microstructure also affects the ultrasonic measurements Ref [22] was given martensite presents high resistance to ultrasound waves, because of its compact and fine granulation.

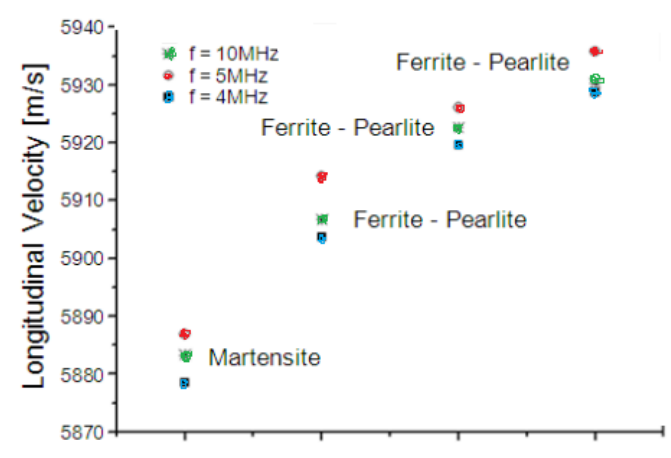

(A)

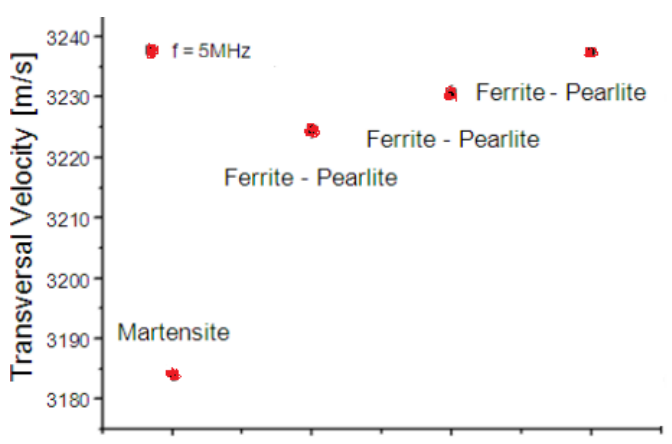

(B)

Figure 12. Ultrasonic velocities $\left(\mathrm{V}_{\mathrm{L}} \& \mathrm{~V}_{\mathrm{T}}\right)$ values in different phases

\subsubsection{Mechanical Properties of Samples}

The tensile properties as shown in table no- 6 of $A_{2}$ samples are almost comparable to $\mathrm{A}_{1}$. This may be due to the presence of some amount of tempered bainite and retain austenite, which improve the strength and ductility in mostly ferrite matrix. Further increase in hardness due to increase in acicularity microstructure. The mechanical properties study of the $\mathrm{B}_{2}$ and $\mathrm{B}_{3}$ reveals a bit of dissimilarity in characteristics to that of steel sample $A_{1}, A_{2}$. A considerable fall in the ductility property of $\mathrm{B}_{2}$ sample due to some amount of retain austenite is not capable of strain-induced transformation. When the steel is continuous cooled a significant improvement in the strength due to increase in acicularity of the microstructure.

Table 4. Corrosion rate $(\mathrm{mm} / \mathrm{yr})$ of steels

\begin{tabular}{|c|c|c|c|c|c|}
\hline \multicolumn{2}{|c}{ Steel } & \multicolumn{4}{c|}{$\mathrm{CR}(\mathrm{mm} / \mathrm{yr})$} \\
\cline { 2 - 6 } & $0 \% \mathrm{NaCl}$ & $0.1 \% \mathrm{NaCl}$ & $1 \% \mathrm{NaCl}$ & $3 \% \mathrm{NaCl}$ \\
\hline & $\mathrm{A} 1$ & 0.361 & 0.539 & 5.467 & - \\
\hline & $\mathrm{A} 2$ & 0.107 & 0.277 & 2.094 & - \\
\hline & A3 & 0.115 & 0.446 & 3.441 & - \\
\hline & A4 & - & 0.351 & 2.704 & 1.076 \\
\hline & A5 & - & 0.247 & 1.313 & 1.066 \\
\hline & A6 & - & 0.128 & 0.619 & 0.874 \\
\hline & B1 & 0.185 & 0.178 & 7.207 & - \\
\hline & B2 & 0.223 & 0.146 & 0.77 & - \\
\hline & B3 & 0.362 & 0.301 & 0.708 & - \\
\hline & B4 & - & 0.316 & 0.9303 & 1.826 \\
\hline & B5 & - & 0.282 & 0.831 & 1.042 \\
\hline & B6 & - & 0.159 & 0.367 & 0.881 \\
\hline
\end{tabular}

Table 5. Corrosion current, I corr (A/ $\left.\mathrm{Cm}^{2} \mathrm{X} 10^{5}\right)$ of steels

\begin{tabular}{|c|c|c|c|c|c|}
\hline \multirow{2}{*}{ Steel } & \multicolumn{5}{|c|}{ Corrosion current, $\mathrm{I}_{\text {corr }}\left(\mathrm{A} / \mathrm{Cm}^{2} \mathrm{X} 10^{5}\right)$} \\
\cline { 2 - 6 } & $0 \% \mathrm{NaCl}$ & $0.1 \% \mathrm{NaCl}$ & \multicolumn{1}{c|}{$1 \% \mathrm{NaCl}$} & $3 \% \mathrm{NaCl}$ \\
\hline $\mathrm{A}_{1}$ & 4.7 & 7 & 71 & - \\
\hline $\mathrm{A}_{2}$ & 1.4 & 3.6 & 27.2 & - \\
\hline $\mathrm{A}_{3}$ & 1.5 & 5.8 & 44.7 & - \\
\hline $\mathrm{A}_{4}$ & - & 3.127 & 9.378 & 9.589 \\
\hline $\mathrm{A}_{5}$ & - & 2.207 & 7.081 & 9.493 \\
\hline $\mathrm{A}_{6}$ & - & 1.143 & 5.518 & 7.788 \\
\hline $\mathrm{B}_{1}$ & 2.4 & 2.3 & 93.6 & - \\
\hline $\mathrm{B}_{2}$ & 2.9 & 1.9 & 10 & - \\
\hline $\mathrm{B}_{3}$ & 4.7 & 3.9 & 9.2 & - \\
\hline $\mathrm{B}_{4}$ & - & 2.812 & 8.288 & 9.261 \\
\hline $\mathrm{B}_{5}$ & - & 2.511 & 7.4 & 7.848 \\
\hline $\mathrm{B}_{6}$ & - & 1.418 & 3.269 & 0.163 \\
\hline
\end{tabular}

In general, the retained austenite can affect the mechanical properties in several ways:

- Residual blocky austenite could transform to martensite 
during water quenching and improve the strength

- Retained austenite inter lath layers could increase the strength by enhancing the ability of lath boundaries to obstacle dislocation movement

- Retained austenite could increase the elongation due to the TRIP effect.

Table 6. Mechanical Properties of TRIP- assisted steels

\begin{tabular}{|c|c|c|c|c|}
\hline STEEL & $\begin{array}{c}\text { UTS } \\
\text { (MPa) }\end{array}$ & $\begin{array}{c}\text { Hardness } \\
\text { ( VHN ) }\end{array}$ & $\begin{array}{c}\text { Work } \\
\text { hardening } \\
\text { exponent (n) }\end{array}$ & $\begin{array}{c}\text { Charpy } \\
\text { impact (J) } \\
-40^{\circ} \mathrm{C}\end{array}$ \\
\hline A1 & 542 & 169 & 0.3526 & 84 \\
\hline A2 & 556 & 151 & 0.6082 & \\
\hline A3 & 681 & 191 & 0.6122 & \\
\hline B1 & 657 & 217 & 0.4184 & 97 \\
\hline B2 & 682 & 179 & 0.4213 & \\
\hline B3 & 812 & 232 & 0.5333 & \\
\hline
\end{tabular}

\section{Conclusions}

Localized corrosion is a serious problem of TRIP assisted steels when they are exposed to chloride solutions. As high-energy regions are prone to corrosion, microstructure having finer grains boundaries have less corrosion resistance. Microstructure contains more low temperature transformation products like bainite and/or martensite and other no equilibrium are more corrosion.

Steel containing more $\mathrm{Cu}, \mathrm{Ni}$ and $\mathrm{Cr}$ is less corrosive compared to other steels having same processing or micro-structure. Steels in rolled condition are more corrosive in both the case, probably due to high dislocation density. The retained austenite in non-Niobium steel is more stable, the non-Niobium steel has shown the optimum combination of mechanical properties. The rate or $\mathrm{i}_{\text {corr }}$ increases and $\mathrm{R}_{\mathrm{p}}$ decreases with increasing $\mathrm{Cl}^{-}$ions in solution up to a threshold value beyond which the corrosion rate starts to decrease. For Nb-containing TRIP steel, the critical $\mathrm{Cl}^{-}$concentration is lesser than its value for the $\mathrm{Nb}$-free sample. This indicates that $\mathrm{Nb}$ micro-alloyed in the TRIP steel favors the formation of oxide films with better insulating character.

The highest ultrasound propagation velocity was observed for ferrite, then for pearlite and finally for martensite, both for longitudinal and transverse waves. Microstructure contains more low temperature transformation products like bainite and/or martensite and other non equilibrium are more corrosion. This behavior was observed in all frequencies used. Ultrasound velocity is mainly affected by the changes in the elastic module of the individual grains that is dependent upon the degree of lattice distortion and disorientation in the prior austenite grains.
For the analyzed steels, the ultrasonic velocity, either longitudinal or transverse waves, increased from the hardest stage (martensite) to the softest stage (ferrite) in all frequencies, while the opposite happened in ultrasonic attenuation.

\section{Acknowledgements}

The results presented in this paper were obtained within the project work of M.Tech thesis in School of materials science and engineering, BESU, shibpur, west Bengal. The authors would like to thank Head \& Director (Ex), Prof.N.R.Bandhyopadhyay with all the faculty members of school of materials science and engineering and Prof.(Dr.) Jayati Datta ,dept. of chemistry, BESU, Shibpur,West Bengal, India for fruitful help for this project. The ndt project part of this work was done in sponsored project work in IIT, kharagpur as a senior research fellow under Dr.Rahul Mitra, dept of metallurgical and materials engg. I would like to thanks to Prof. (Dr.) K.K.Roy, IIT, kharagpur, dept of metallurgical and materials engg for special help to do this project work sponsored by DRDL, Hyderabad. India. The author (AT) expresses his gratitude to DRDL, Hyderabad for the award of a senior research fellowship in HTA project, IIT, Kharagpur.

\section{REFERENCES}

[1] G.Frommeyerand,O.Grassel:HighstrengthTRIP/TWIPsuperp lasticsteels:Development,properties,Application,LaRevueDe, MetallurgieCIT,october,1998,1299

[2] Ultra light steel auto body-advanced vehicle technology (ULSAB-AVC)overviewreport,IISI,2002,p.66,www.worldau toteel.org.

[3] V.F. ZACKAY, E.R.PARKER, D. FAHR AND R. BUSCH: Trans. ASM, 60 (1967), p. 252

[4] Krüger L, Meyer LW, Brüx U, Frommeyer G \& Grässel O Stress-deformation behaviour of high manganese (Al, Si) TRIP and TWIP steels. J Phys IV 110: 189-194(2003).

[5] Frommeyer G, Brüx U \& Neumann P (2003) Supra-Ductile and High-Strength Manganese-TRIP/TWIP Steels for High Energy Absorption Purposes. ISIJ Int 43:438-446.

[6] Han YS \& Hong SH (1997) The effect of Al on mechanical properties and microstructures of Fe32Mn-12Cr-xAl-0.4C cryogenic alloys. Mater Sci Eng A 222:76-83.

[7] Matsumura, O., Sakuma, Y. and Takechi, H.Transactions of the Iron and Steel Institute 27 (1987) 570.

[8] J. R. Challande (M. S. Thesis) UCRL-18475, (1968).

[9] F.J.Padilla(M.S.Thesis) UCRL-19678, (1970).P.J. JAQUES, J. LADRIERE, F. DELANNAY, Metall.Trans.32A, (2001); p. 2759 .

[10] Khoshnaw F.M., Kheder A.I., Ali F.S.M. (2007): Corrosion behavior of nitrided low alloy steel in chloridesolution, Anti-Corrosion Methods and Materials,54/3,pp.173-179.doi: 


\section{$10.1108 / 000355907107486441$}

[11] Chen Y.Y., Tzeng H.J., Wei L.I., Shih H.C. (2005): Mechanical properties and corrosion resistance of low-alloy steels in atmospheric conditions containing chloride, Materials Science \& Engineering A, 398, pp. 47-59.doi:10.1016/j.msea.2005.02.064

[12] Turnball A., Zhou S. (2008): Impact of temperature excursion on stress corrosion cracking of stainless steels in chloride solution, Corrosion Science, Vol. 50, pp. 913-917. doi:10.1016/j.corsci.2008.01.020

[13] Sadhukhan S., Das K. P., Bandyopadhyay N. R. and Banerjee M. K. Journal of the Institution of Engineers, India, 82 (2001) 65.(6).Bhadeshia, H. K. D. H. and Honeycombe, R. W. K. Steels: Microstructure and Properties, Elsevier, UK, (2006)

[14] Takechi,H.,Matsumura,O.,Sakuma,Y.Japan Kokai Tokyo KohoJapan Patent 62,188,729 (1987)

[15] Matsumura, O., Sakuma, Y. and Takechi, H. Transactions of the Iron and Steel Institute 27 (1987) 570

[16] Kim, S. A. and Johnson, W. L., 2007, "Elastic constants and internal friction of martensitic steel, ferritic-pearlitic steel,and $\alpha$-iron", Material Science and Engineering A, 452-453, pp 633-639.

[17] Hakan, C.G.andOrkun, B.T., 2005, "Characterization of micro structural phases of steels by sound velocity measurement', Materials Characterization Vol. 55, pp. 160-166.

[18] R. Prasad, S. Kumar, Journal of Materials Processing and Technology. 42 (1994) 51-59.

[19] C.H. Gür, B.O. Tuncer, Materials Characterization. 55 (2005) 160-166.

[20] V.H.C. de Albuquerque, T.A.A. Melo, D.F. de Oliveira, R.M. Gomes, J.M.R.S. Tavares, Materials \& Design, DOI: 10.1016/j.matdes.2010.02.010

[21] P. Palanichamy, A. Joseph, T. Jayakumar, Baldev Raj, NDT \& E International. 28 (1995) 179-185

[22] S.A. Kim, W.L. Johnson, Materials Science and Engineering: A. 452-453 (2007) 633-639. 